\title{
Fibrillary Neoplastic Astrocyte
}

National Cancer Institute

\section{Source}

National Cancer Institute. Fibrillary Neoplastic Astrocyte. NCI Thesaurus. Code C37129.

A neoplastic astrocyte characterized by the presence of an atypical nucleus (large, irregular, or hyperchromatic), scant amount of cytoplasm, and cell processes that contribute to the formation of a fibrillary matrix. 